\title{
DINÂMICAS DE NEGOCIAÇÃO E CONFLITO ENTRE TERREIROS E TRAFICANTES EVANGELIZADOS NAS FAVELAS CARIOCAS
}

NEGOTIATION AND CONFLICT'S DYNAMICS BETWEEN RELIGIOUS TERREIROS (MEETING PLACES) AND EVANGELIZED DRUG DEALERS IN THE FAVELAS OF RIO DE JANEIRO

\section{Carolina Rocha}

Mestre em História pela Universidade Federal Fluminense (UFF). Professora do curso de Pós-graduação Estado e Relações Étnico-raciais na Universidade Castelo Branco (UCB). Autora do livro O sabá do sertão: feiticeiras, demônios e jesuítas no Piauí colonial (Paco Editorial, 2015). Atualmente cursa o doutorado em Sociologia no Instituto de Estudos Sociais e Políticos da Universidade do Estado do Rio de Janeiro (IESP/UERJ). Em escolas públicas, desenvolve oficinas sobre racismo, cultura afro-brasileira e intolerância religiosa. É pesquisadora da Coordenadoria de Experiências Religiosas Africanas e Afro-brasileiras, Racismo e Intolerância Religiosa, vinculada ao Laboratório de História das Experiências Religiosas da Universidade Federal do Rio de Janeiro (LHER/UFRJ). Membro da Associação Brasileira de História das Religiões (ABHR) e do Congresso Brasileiro de Pesquisadores Negros (COPENE). 


\section{RESUMO}

O artigo a seguir apresenta dados e reflexões sobre a violência empregada contra adeptos de religiões afro-brasileiras em favelas cariocas após o vertiginoso crescimento de igrejas denominadas (neo)pentecostais. Há registros de terreiros sofrendo ataques e sanções protagonizados por traficantes de drogas, pastores e moradores "em nome de Jesus" desde o final dos anos 1980. Em 2006, o líder do varejo de drogas em grande parte das favelas da Ilha do Governador, na zona norte do Rio de Janeiro, ordenou o fechamento de todos os terreiros nas áreas onde atuava. Em contrapartida, esses espaços permanecem em algumas áreas. Na favela da Serrinha, localizada no bairro de Madureira, a situação é igualmente multifacetada. Busca-se, assim, compreender as múltiplas formas de aproximação, conflito e negociação travadas entre os diversos atores que compartilham o cotidiano desses lugares.

Palavras-chave: religião; conflito; varejo de drogas; conversão.

\section{ABSTRACT}

The following article presents data and reflections on the violence against Afro-Brazilian religions in some Rio de Janeiro favelas influenced by the vertiginous growth of denominated (neo) Pentecostal churches. According to the records, Terreiros have been suffering attacks and sanctions from drug traffickers, pastors and residents "in the name of Jesus" since the late I980s. In 2006, the drug trafficking leader in most Favelas located at Ilha do Governador, in the northern area of Rio de Janeiro, ordered the closure of all the Terreiros in the areas where he operated. In contrast, the Terreiros remain in some areas. In the Serrinha favela, located at Madureira neighborhood, the situation is also multifaceted. It aims to understand the multiple approaches, conflict and negotiation between the different actors who share the daily life of these places.

Keywords: religion; conflict; drug trafficking; religious's conversion. 


\section{Introdução}

O que se convencionou mais recentemente chamar de intolerância religiosa foi resultado do processo de colonização do Brasil, deixando suas marcas no âmbito cultural e político-estatal até os dias atuais. Assim, observa-se a presença constante da intolerância religiosa em nossa história, com mudanças que dizem respeito aos atores que a perpetraram/perpetram (ora colonizadores, ora agentes do estado, ora líderes religiosos) e aos argumentos que baseavam/baseiam suas ações (CUNHA, 2OI2).

Dessa maneira, episódios violentos acerca da destruição de terreiros e ofensas a símbolos religiosos afro-brasileiros são documentados desde o final do século XIX no país. O Código Penal de I89o, por exemplo, criava mecanismos legais para combater os chamados "feiticeiros" (MAGGIE, I992). As religiões afro-brasileiras foram alvo da Igreja Católica e do Estado, que procurou estigmatizar ritos e símbolos, ligando-os à criminalidade e ao Diabo. Atualmente, as igrejas neopentecostais têm sido acusadas de preconceito, violência, fundamentalismo e intolerância, pois sua teologia tem levado até as últimas consequências discursos e práticas de ódio e demonização.

O pentecostalismo teve crescimento mundial a partir da década de I960, principalmente dentro dos contextos de maior precariedade político-social. A missão pentecostal manteve seu foco nas pastorais destinadas ao meio urbano, considerado fonte de intensas "batalhas espirituais" entre o bem e o mal, entre Deus e o Diabo. Na perspectiva teológica e doutrinária dos evangélicos pentecostais o mundo é um local de guerra, e o linguajar bélico empregado pelos pastores, a respeito do "inimigo" a ser combatido e do "exército do senhor" a ser convocado, comunica bem com os moradores de favelas e periferias pobres, notadamente, com o discurso empregado no varejo de drogas.

Além disso, a proximidade e a vida similar entre pastores e moradores das favelas geram uma empatia maior com relação ao culto, diferentemente do que acontecia com os padres da Igreja Católica, por exemplo, que residiam em áreas distantes. $\mathrm{O}$ acesso facilitado ao culto e a ampla oferta de igrejas (observa-se o desembaraço de fundar templos em decorrência de cisões religiosas frequentes), que cresciam de maneira menos verticalizada e hierarquizada que o catolicismo oficial, também eram fatores que contribuíam para a evangelização de um número cada vez maior de fiéis.

Outro aspecto importante que colaborava para popularizar o culto era o grande acolhimento promovido pelas igrejas: os "irmãos" geravam uma rede de solidariedade e proteção que envolvia com afeto e confiança o membro novo, geralmente habituado com um ambiente inseguro e vulnerável. As igrejas eram formadas por circuitos de reciprocidade que favoreciam as relações materiais entre seus membros, com o incentivo à ajuda mútua e aos 
impulsos empreendedores. O fiel era enraizado na igreja, vivida por ele como totalidade social, espiritual e familiar (CUNHA, 2009).

A conversão também possibilitava para o morador da favela o respaldo moral e ético dentro de um contexto que envolvia pobreza, violência e criminalidade: "por manterem uma postura segregadora em relação ao 'mundo secular' e às 'coisas do mal' é que os pentecostais conseguem uma posição de respeito [...]" (TEIXEIRA, 2006, p. 5I). Assim, em algumas favelas, as mães de santo, enfraquecidas social e politicamente, iam perdendo espaço para os evangélicos "guardiões da moral" e propagadores da "verdade" que conseguiam fornecer um manto de respeitabilidade e crédito para moradores afetados pelo estigma do racismo e da criminalização da pobreza.

O crescimento neopentecostal, a partir dos anos 1970-1980, centralizava ainda mais o discurso teológico anterior no modelo da "batalha espiritual", investindo no proselitismo religioso justificado por uma necessidade de cura, promovendo uma convocação nacional da libertação, principalmente por meio da mídia televisiva, e aproveitando-se do apelo mágico exigido pelos fiéis. No meio de todo esse contexto assiste-se à criação de um dos maiores símbolos do crescimento neopentecostal no Brasil: a Igreja Universal do Reino de Deus. Insuflados pela crença na teologia da "cruzada espiritual", os fiéis lutavam com os demônios das religiões afro-brasileiras, seu principal alvo (graças a eficácia reduzida dos ataques aos símbolos do catolicismo, religião ainda majoritária e hegemônica) (PEREIRA, 2OI3).

O neopentecostalismo, diferentemente do que foi o pentecostalismo clássico ascético das décadas anteriores, se aproximava e se apropriava do sistema simbólico de manipulação mágica da umbanda e do candomblé para depois negá-lo e demonizá-lo: "O fiel neopentecostal acaba por visualizar, espelhado em um candomblé que ele mesmo constrói, o seu 'mal libertador', fazendo da violência um ato sagrado e religioso de libertação e de ocupação da fonte geradora de malefícios" (REINHARTDT, 2007, p. 32).

O elemento principal de inversão e mediação desse discurso esteve concentrado em protagonistas específicos, os exus, tidos como diabos que proliferavam o mal pelo mundo (PEREIRA, 20I3). Assim, os altares dos templos neopentecostais viravam grandes palcos de exorcismos de pessoas incorporadas por exus ${ }^{1}$ que desejavam disseminar o ódio e a guerra de acordo com a sua perspectiva.

\footnotetext{
${ }^{1}$ Os exus cultuados na umbanda são espíritos que viveram no mundo carnal e após a morte passaram a incorporar seus espíritos em médiuns na forma de exus (entidade masculina) e pombagiras (entidade feminina) para fazer trabalhos espirituais de caridade e evoluir espiritualmente. Por ainda estarem em processo evolutivo, são apegados à vida terrena e, em alguns casos, podem beber e fumar. Seu caráter não é plenamente definido, portanto devem ser doutrinados pelos pais de santo para propagarem a prática do bem. Exus são, por isso, subordinados intermediários entre o mundo terreno (ayé) e o mundo dos deuses (orum).
} 
Nesse cenário, era possível estabelecer uma relação de reciprocidade de interesses entre as igrejas neopentecostais e os traficantes das favelas locais. A igreja oferecia uma forte proteção, representada pelos irmãos de fé, valorizada pelo discurso da guerra contra o "inimigo" e incentivada pela busca da prosperidade material, conferindo um aspecto moral reconfortante aos traficantes convertidos, que embora ainda não estivessem totalmente libertos de suas atividades, estavam em vias de recuperação e vislumbravam um horizonte seguro de salvação. Os traficantes, por sua vez, grande foco de influência dentro das favelas, conferiam poder aos líderes evangélicos a partir da admissão e da constatação de sua autoridade moral e espiritual. Assim, através dessas alianças, como defende Christina Vital (20IO), essas igrejas tornavam-se, muitas vezes, forças religiosas e políticas no âmbito local e supralocal.

O neopentecostalismo assumia, em consequência, um caráter popular inegável nas favelas cariocas, com um modelo não institucional e expressões religiosas sincréticas que se desenvolviam em contextos de violência e criminalidade. As complexas relações entre traficantes e evangélicos eram mediadas por um combate central, a guerra entre Deus e o Diabo. Entretanto os vínculos estabelecidos entre ambas as partes sempre foram tensos e por vezes ambíguos, pairando entre o limiar da ajuda e/ou da cumplicidade. Nenhum irmão evangélico, considerado um ser moralmente superior, desejaria ser identificado às atividades ilícitas do tráfico, no entanto, o apoio do "chefe" local era muito importante para dar legitimidade e liberdade de circulação ao grupo religioso.

Por outro lado, o comportamento dos "bandidos" em relação ao funcionamento dos terreiros não foi uniforme, pois nem todos proibiram expressamente as atividades religiosas desses espaços. Desse modo, não se pode afirmar que a "conversão" dos traficantes de drogas e a possibilidade de fornecerem respaldo moral e financeiro para certas igrejas sejam fatores suficientes para explicar a crescente popularidade do discurso neopentecostal nas favelas e nas periferias do país. As múltiplas formas de sociabilidade presentes nas favelas cariocas, mediadas por códigos de conduta dinâmicos, constantemente transformados e ressignificados, dificulta qualquer tentativa simplista e generalista de tentar explicar esses processos.

\section{Quando a história da pesquisadora é parte da história}

Como pressuposto teórico-metodológico, dentro de um trabalho com inspiração etnográfica, optei por utilizar "cenas descritivas" (TELLES; HIRATA, 2007, p. I77), algumas que vivenciei e presenciei, e outras que são trazidas à tona pelos testemunhos dos meus interlocutores que permitam elucidar as diferentes conexões, as mediações, os conflitos e as negociações travadas nas relações estabelecidas no campo: 
Não se trata de partir de objetos ou "entidades sociais" tal como se convencionou definir de acordo com os protocolos científicos das ciências sociais, mas sim de situações e configurações sociais a serem tomadas como cenas descritivas que permitam seguir o traçado dessa constelação de processos e práticas, suas mediações e conexões [...]. (TELLES; HIRATA, 2007, p. I77).

Dessa maneira, tomo como ponto inicial, e primeira cena etnográfica, o conjunto de episódios que vai definir o tema da minha tese de doutorado - que inspira esse artigo - e desenhar, a partir de então, o percurso da minha entrada em campo. Como filha de santo ${ }^{2}$ de uma casa de candomblé na Ilha do Governador (RJ) e praticante da religião há mais de dez anos, me habituei a ouvir histórias sobre a aproximação do varejo de drogas com as religiões genericamente denominadas como evangélicas na região. Observei meu pai de santo $^{3}$ comentar algumas vezes sobre a perseguição engendrada por igrejas, pastores e traficantes de drogas a terreiros ${ }^{4}$ de umbanda e candomblé no bairro, sobre o fechamento de casas religiosas e sobre a dificuldade de realizar festas em algumas favelas.

O impulso para que eu decidisse definitivamente pesquisar o assunto, surgiu em março de 20I4. Fui iniciada ${ }^{5}$ no candomblé em 201 I e, após esse primeiro passo, deve-se cumprir outros rituais específicos com o passar dos anos. Em 20I4, completei três anos de iniciação e fui para a casa de santo realizar as cerimônias correlatas. No entanto, em razão de um problema de falta de água, na ocasião, uma irmã de santo precisaria levar as roupas destinadas a vestir os santos e as pessoas do terreiro para lavar em sua casa. Muito constrangida, ela disse que não poderia fazê-lo. Moradora do morro do Dendê, aquela mulher tinha muito medo de lavar e secar as roupas em casa, pois "na favela todo mundo vê tudo", e ela podia ser perseguida se soubessem da sua religião. As roupas foram lavadas na minha casa e o episódio não saiu da minha cabeça. Após concluir todas as atribuições religiosas, decidi escrever um projeto de doutorado sobre a intolerância religiosa sofrida pelos adeptos de religiões afro-brasileiras nas favelas da Ilha do Governador, destacando a violência e o medo como forças motrizes desse processo.

O morro do Dendê, que era controlado por Luiz Telles, morto em 2019, é a maior favela do bairro e um dos principais pontos de venda de drogas do Rio de Janeiro. Grande parte das

\footnotetext{
${ }^{2}$ Mulher que integra uma casa religiosa de matriz africana.

${ }^{3}$ Chefe espiritual da casa religiosa.

${ }^{4}$ Aqui entendidos como casas religiosas com fins espirituais ligados à umbanda e ao candomblé.

${ }^{5}$ A iniciação ou o "fazer santo" é um momento ritualístico de entrada da pessoa na religião, em que se aprendem as rezas, as cantigas, os preceitos e os segredos só confiados aos iniciados do candomblé.
} 
outras favelas da região é chefiada por ele e pelos seus aliados. Porém as "bocas de fumo" não são as únicas fontes de renda do grupo, e é possível que grande parte do dinheiro arrecadado venha das comissões pagas por comerciantes e empresas de ônibus locais em busca de proteção contra roubos e furtos, do transporte alternativo feito por vãs, kombis e moto-táxis, que pagam pedágios semanais ao grupo, da venda de botijões de gás, das máquinas de caçaníqueis e das operadoras clandestinas de tevê "a gato".

Em 2006, Luiz, o chefe do tráfico na região, que até então recorria à orientação espiritual do candomblé, passou a frequentar a Assembleia de Deus Ministério Monte Sinai, e proibiu o funcionamento de todos os terreiros dentro das favelas sob seu domínio. No morro do Dendê foram fechadas dez "casas de santo", e paralelamente ao surgimento de dezenas de pequenas igrejas a cada semana, só resta um terreiro em atividade no local, que se manteve intacto durante os conflitos religiosos na área. Luiz exibe no antebraço direito uma tatuagem com o nome Jesus Cristo e usa uma pistola banhada a ouro com a inscrição: "Jesus". ${ }^{6}$

Os terreiros de umbanda e candomblé nas favelas da Ilha do Governador começaram a sofrer violência sistemática a partir de 2008, quando a maior parte das casas religiosas localizadas no morro do Dendê foi fechada. As notícias geraram grande repercussão na mídia e mobilizaram candomblecistas e umbandistas pelo país, que se reuniram num protesto em frente à Assembleia Legislativa do Estado do Rio de Janeiro (ALERJ) para discutir o tema da intolerância religiosa.

Alguns irmãos e irmãs de santo $^{8}$ que moravam nos locais onde a perseguição foi mais violenta e intermitente, me contavam sobre as dificuldades de usar os seus fios de conta ${ }^{9} \mathrm{e}$ as roupas que pudessem ser identificadas como de sua religião. Eu mesma, na volta para casa após as festas do meu terreiro, em horários avançados da madrugada, com roupas e acessórios característicos do candomblé - tais como a saia branca rodada, o ojá ${ }^{10}$ na cabeça e os fios de conta no pescoço -, fui questionada sobre o risco dessa exposição. Irmãos e irmãs de santo, familiares, vizinhos e até os mendigos me alertavam sobre o perigo de ser ameaçada ou castigada por externar minha fé nas ruas da Ilha do Governador. No fundo, eu sentia medo, mas por sorte ou destino, nunca tive problemas com isso.

\footnotetext{
${ }^{6}$ Conforme saiu em reportagem do jornal Extra em 7 set. 2013.

${ }^{7}$ Desses protestos surgiu a Comissão de Combate à Intolerância Religiosa (CCIR), de caráter ecumênico.

${ }^{8}$ Como chamam uns aos outros os filhos de santo de uma casa de umbanda ou candomblé.

${ }^{9}$ Colar usado pelos adeptos de religiões de matriz africana, geralmente feito de miçangas que, dependendo da cor, indicam um orixá, ou seja, ancestrais divinizados africanos. Representam muitas vezes proteção para quem usa.

${ }^{10}$ Tipo de torço ou turbante usado na cabeça pelos adeptos das religiões afro-brasileiras.
} 
A estética das favelas da Ilha do Governador mudou bastante com o tempo. Quando criança morei no morro do Dendê por alguns anos e lembro de ver muitas imagens de São Jorge e Nossa Senhora nas praças, os muros da favela grafitados com letras de funk e de samba, misturadas a orações católicas, símbolos da facção Terceiro Comando Puro (TCP) e imagens de exus e pombagiras. ${ }^{11} \mathrm{Na}$ minha vida adulta, já pude testemunhar uma favela cercada de igrejas, a maioria de orientação neopentecostal, na qual a realização de cultos ao ar livre era constante, e com muros repletos de dizeres e imagens bíblicas.

Meu padrinho, que morava no morro do Dendê desde criança, era, sem dúvida, um "cria do morro", como dizia meu pai. Ele tinha um comércio local e há décadas vendia bebidas "quentes", como uísque, vodca, caipirinha e outros drinks feitos à base de destilados no baile funk local. Ele não tinha um bom relacionamento com o "chefe" do varejo de drogas. Não sei ao certo o motivo, mas ele sempre me dizia que os bandidos não gostavam de pagar pelo que bebiam e comiam, e que ele era da época em que traficante respeitava os "crias do morro" e não fazia covardia. O padrinho sempre foi do candomblé, mas frequentava terreiros escondido há alguns anos para não acirrar os conflitos com o "dono do morro", então "evangelizado". ${ }^{12}$

Lembro-me de uma cena específica que me impactou na época. Era aniversário do padrinho e fui com meu pai a um churrasco em sua casa. Após o churrasco, ele me pediu que o ajudasse na barraca do baile porque sua esposa estava doente e um dos seus ajudantes não compareceu no dia. Eu topei, pois estava animada com a possibilidade de ir pela primeira vez no famoso baile funk do Dendê, que contava, na época, com a participação de artistas famosos, jogadores de futebol e muita gente da zona sul do Rio de Janeiro. Estava com medo da exposição de armas e drogas, mas a cena que se descortinava na minha frente, um misto de escuridão com luzes coloridas desconexas, me deixava ver pouca coisa. Até que, magicamente, por volta da meia-noite, as luzes se acenderam e começou um culto. À frente, um famoso pastor, conhecido por evangelizar nos complexos penitenciários cariocas, vestindo terno preto, gravata vermelha e com o microfone em punho. As pessoas em volta, em uma mistura de euforia e excitação, gritavam o nome de Jesus Cristo até que um silêncio aterrador tomou conta de todos. Logo se formava uma enorme fila, encabeçada pelo pastor que, ao tocar no primeiro da fila, fazia com que todos os outros caíssem no chão atrás dele, em efeito dominó. Em seguida, foram feitas orações e grupos de cantores evangélicos tomaram conta do palco. Cerca de uma hora depois tudo voltava a ser como antes, com a

\footnotetext{
${ }^{11}$ Entidades espirituais da umbanda, o exu ligado a espíritos masculinos e, a pombagira, ligada a espíritos femininos.

12 Usarei o termo evangelizado para caracterizar os traficantes que explicitamente externam sua fé dentro de religiões pentecostais ou neopentecostais.
} 
escuridão, as luzes coloridas, os funks conhecidos como "proibidões" tocando e o consumo de bebidas e drogas ilícitas.

Essas imagens ficaram muito tempo na minha cabeça. A cada dia surgiam novas informações sobre o traficante evangelizado da Ilha, fosse no jornal, na televisão ou no cotidiano dos moradores do bairro. Não havia pensando em transformar essas experiências em pesquisa antropológica até fins de 2013, momento em que as histórias sobre traficantes "convertidos" nas favelas cariocas, e a consequente perseguição aos cultos de matriz afro, ganhou novo fôlego na imprensa. O jornal Extra fez matérias de capa e dedicou muitas páginas para falar do que ocorria na Ilha, em Acari, na Cidade de Deus, dentre outras favelas.

\section{Novas perspectivas diante da complexidade do campo}

Inicialmente esta pesquisa teria como problemática principal a intolerância religiosa nas favelas da Ilha do Governador, tomando como ponto de partida a "conversão" ${ }^{13}$ do traficante Luiz e a consequente violência empregada contra os terreiros de umbanda e candomblé dessas áreas. Entretanto o desenvolvimento do trabalho revelou casos empíricos complexos que extrapolaram os objetivos iniciais. O trabalho de campo e as entrevistas já realizadas foram capazes de redesenhar parte dos objetos e dos objetivos do projeto de tese proposto. Optei por realizar um estudo comparativo entre duas favelas específicas da Ilha do Governador: o morro do Dendê e o morro do Barão, reconhecidos como casos emblemáticos nas falas dos interlocutores.

Enquanto no Dendê a violência empregada contra as "casas de santo" foi sistemática após a "conversão" do traficante, o sentimento de medo é generalizado e há apenas um terreiro em funcionamento na área, dividindo espaço com dezenas de igrejas; no Barão, a situação é inversa, existem quatro terreiros e apenas duas igrejas, e o sentimento de tolerância e liberdade religiosa prevalece. No morro do Barão, o código de conduta predominante é o das religiões afro-brasileiras, representadas pela umbanda e pelo candomblé, os pais de santo possuem terreiros tradicionais na área e são respeitados pelo tempo em que residem na favela. As igrejas, que surgiram depois, precisaram negociar com eles uma forma de bom convívio. O local não tem "bocas de fumo" e não há presença permanente e nem circulação de traficantes armados, tal como no Dendê. No entanto a área está sob a responsabilidade do traficante Luiz.

No Barão, constatou-se uma postura bem diferente dos moradores em relação à religião. Enquanto no Dendê e em outras favelas da Ilha as pessoas demonstraram grande medo

\footnotetext{
${ }^{13}$ As palavras entre aspas identificam expressões nativas presentes nas falas dos interlocutores. 
acerca da exteriorização da fé em religiões afro-brasileiras, nessa favela, o medo efetivo de uma perseguição religiosa é praticamente inexistente. No Dendê, mesmo os terreiros tradicionais, com pais de santo que nasceram na favela, foram destruídos e demonizados para emergir uma nova ordem moral imposta pelo traficante "recém-convertido": ${ }^{14}$ a doutrina cristã pentecostal. A religião do "chefe" passou a ser a religião imposta a todo o território, predominando as relações conflituosas entre os "evangélicos" ${ }^{15}$ e os moradores identificados genericamente como "macumbeiros", que ainda persistem no local, mesmo de maneira muito discreta. É interessante notar como, atualmente, tem sido gerida a questão dentro de algumas favelas cariocas, que deixou de ser uma opção meramente individual, de foro íntimo e privado do indivíduo, para se tornar uma prática representativa de todo o coletivo, imposta pelo varejo de drogas.

Assim, três códigos de conduta distintos e interligados - do varejo de drogas, das igrejas neopentecostais e das religiões afro-brasileiras - aparecem condensados na figura de um indivíduo capaz de estabelecer uma forma específica de controle social, econômico e religioso nas favelas da Ilha do Governador há doze anos. A comparação entre as duas favelas do mesmo bairro, o Dendê e o Barão, parece bem elucidativa pelas diferenças marcantes na maneira como o varejo de drogas se estabelece no território que, por sua vez, produz rearranjos sociais distintos nas formas de aproximação e afastamento com os adeptos das religiões afro e os moradores locais.

Isso não significa que não existam pontos de congruência nas relações travadas no seio das duas favelas. No Dendê, por exemplo, apesar da ampla perseguição aos cultos afrobrasileiros, ainda existe um terreiro de candomblé em funcionamento, convivendo com dezenas de novas congregações neopentecostais. Alguns rumores apontam que ele é comandado pela madrinha do traficante, e por isso permanece intacto. Outras pessoas sugerem que a mãe de santo possa manter uma relação estreita com o tráfico e/ou com pastores locais, na tentativa de garantir sua permanência. Da mesma maneira, um ataque violento, no início de 2015, a uma casa de umbanda situada na principal rua de acesso ao morro do Barão abalou por algum tempo a rotina de paz ecumênica que imperava no lugar. O pai de santo responsável diz que se tratou de um caso de intolerância religiosa, mas grande parte dos vizinhos e dos moradores do Barão apontam que, na verdade, o ato violento foi

\footnotetext{
14 Usarei os termos "conversão" e/ou "convertido" entre aspas. Não há consenso entre religiosos neopentecostais e nem entre homens e mulheres que trabalham no tráfico de drogas nas favelas cariocas sobre essa conversão. Alguns vão dizer que a conversão efetiva só ocorre após o criminoso(a) abandonar definitivamente suas atividades ilícitas, outros dirão que o mínimo de aproximação com a igreja já anuncia e, portanto, confere uma conversão, pois se trata de um processo que levará à libertação total da criminalidade no futuro.

15 Termo genérico utilizado pelos interlocutores para se referirem a todos os irmãos convertidos às religiões de denominação protestante, notadamente os pentecostais e neopentecostais.
} 
motivado por uma vingança de um ex-filho de santo do terreiro, que dias antes havia sido humilhado pelo "zelador de santo". ${ }^{16} \mathrm{O}$ caso ainda está sendo investigado, mas independentemente do veredito foi suficiente para causar um sentimento de medo e insegurança nunca vivenciado antes no Barão, mesmo que não tenha acontecido exatamente dentro da favela.

Desse modo, mais do que investigar e compreender a "evangelização" dos traficantes de drogas, fenômeno inserido no contexto do crescimento vertiginoso das igrejas pentecostais e neopentecostais no Brasil nas últimas décadas, e a repressão com que passaram a ser tratadas as religiões afro-brasileiras nos seus domínios, objetiva-se alcançar as múltiplas e complexas intercessões difundidas entre atores sociais diversos que compartilham o cotidiano nesses espaços - e assim fugir de generalizações abstratas que relacionam o crescimento neopentecostal nas favelas apenas à conversão dos traficantes ou à perda de prestígio das religiões afro nesses espaços. Isso será alcançado pela adoção de uma perspectiva de análise situacional ou interacional que considera a microssociologia das relações locais e suas múltiplas formas de conflito, aliança e negociação.

\section{Um novo rumo para a pesquisa: várias favelas conectadas por uma única etnografia}

A pesquisa etnográfica nas favelas da Ilha do Governador seguia seu rumo sem mais alterações até o dia 30 de abril de 20I6, quando fui convidada para ministrar uma palestra sobre intolerância religiosa na Casa do Jongo, situada na Rua Compositor Silas de Oliveira, um dos acessos à favela da Serrinha, no bairro de Madureira. O jongo, dança de origem africana, foi tombado pelo Instituto do Patrimônio Histórico e Artístico Nacional (IPHAN) como o primeiro bem imaterial do estado do Rio de Janeiro, e ganhou um espaço oficial com a transformação da sede do Grupo Cultural Jongo da Serrinha em Casa do Jongo, no final de 2015.

Apresentei, na ocasião, dados sobre a pesquisa desenvolvida no doutorado e fui interpelada por uma moradora da Serrinha sobre o chefe do tráfico nas favelas da Ilha do Governador e sua aproximação com grupos religiosos pentecostais e neopentecostais: "o tal fulano da Ilha é amigo do traficante daqui e tentou impor essa religião aqui, mas a mulherada do jongo não deixou, porque aqui ele não tem vez não [...] se esse dono da Ilha fosse da Serrinha já tinha morrido". Continuei com o debate e no final fui conversar com Mônica ${ }^{17}$ para entender melhor o que aconteceu na Serrinha. É importante ressaltar que ela é de uma família tradicional no jongo e colabora com diversos projetos sociais. Mônica me contou que,

\footnotetext{
${ }^{16}$ Zelador de santo é o mesmo que pai de santo.

${ }^{17}$ Os nomes mencionados nas entrevistas foram alterados para preservar a identidade dos interlocutores.
} 
por volta de 20Io, o traficante da Ilha, Luiz Telles, que já estava propagando sua nova fé e fechando os terreiros de umbanda e candomblé locais, tinha sugerido aos chefes do tráfico da Serrinha fazer a mesma coisa, e apresentou pastores a eles. Segundo seu relato, a Ilha e a Serrinha têm ligações estreitas no que tange ao comércio de drogas e amizades pessoais entre os envolvidos. As duas favelas fazem parte da facção Terceiro Comando Puro (TCP).

Mônica contou que Lucas Santos Borges, conhecido como Mequinho, era o chefe do tráfico na Serrinha e contava com o apoio dos seus dois irmãos, Linho e Cerol. Os moradores da Serrinha apontam Mequinho como um traficante extremamente violento, com o que Mônica concorda, mas faz a ressalva: "ele era justo". Segundo ela, havia muitos boatos de que ele tinha feito um pacto com o demônio, porque Mequinho fazia "sacrifícios humanos", que na prática significava matar as pessoas e beber o sangue delas:

Ele era um cara que tinha boca e não falava, sempre trabalhou, de repente virou essa coisa toda, de matar, de corta cabeça, isso e aquilo... Ele nunca tinha usado droga, passou a fumar, cheirar, bebia cachaça pura, aí quando ele não tava muito bem, aí dizia que ele tava meio que incorporado, entendeu? Mas era muito temido.

O traficante frequentava terreiros de umbanda e candomblé e apoiava a religião na favela. Entretanto uma das suas irmãs, Lúcia, pastora de uma igreja neopentecostal, teria ameaçado fechar algumas casas de santo com o apoio de Linho e Cerol, então "convertidos". Mônica me contou que Lúcia era autoritária e "se achava a dona da Serrinha":

E ela abriu uma igreja aqui na comunidade e falou que ia acabar com os centros espíritas. Sendo que aqui a nossa comunidade tem voz seja com o tráfico, seja com qualquer um, porque a maioria dos traficantes são crias do local, ainda têm o respeito à localidade, aos moradores e aos mais velhos. Mas eles chegaram a ir a algumas casas de santo, quebrar santo, entendeu?

$\mathrm{Na}$ época, Vó Nitinha, herdeira de uma família tradicional de jongueiros, indignada com os boatos e os desmandos da pastora, provocou os traficantes e questionou se teriam poder e coragem para fechar sua casa. Segundo relatos, nenhum membro do tráfico "ousou" procurar Vó Nitinha, benzedeira há mais de 70 anos, para proibir seu culto, no entanto, outras casas religiosas foram ameaçadas e quebradas:

Então a Serrinha já é uma comunidade conhecida por essa resistência cultural, na verdade. Fundada por negros descendentes de escravos que já vieram dessa veia de resistência. O jongo, o samba, a cultura negra, na verdade. Até hoje esses ensinamentos de resistência continuam muito aflorados. Porque muita gente saiu da Serrinha, que melhorou de vida e tal, 
foi pra outros lugares. Mas existe muita gente tradicional da época antiga, como a Vó Nitinha, que é minha mãe, entendeu? É muito respeitada, né? Tradicionalmente, pelo poder paralelo, que é o tráfico de droga, pelos moradores, todo mundo.

Mônica, em conjunto com outras mulheres da Serrinha, procurou o traficante Mequinho para denunciar o que chamou de "abusos feitos em nome de Deus", e o traficante reagiu desautorizando os irmãos e garantindo que todos podiam expressar sua religião livremente: "Aí ele falou assim: 'do portão da sua casa pra dentro, quem manda é você, você pode fazer o que você quiser. E diz que fui eu que mandei. Se isso é ordem dos meus irmãos, eu estou contradizendo essa ordem, porque quem manda sou eu'".

Mequinho foi assassinado em 20I2, e seu irmão Cerol se uniu a outro traficante da área, conhecido como Ostra, nomeado pelo próprio Mequinho como seu sucessor para garantir o domínio do grupo de sua família na Serrinha. Cerol morreu algum tempo depois, e hoje a favela é dominada por Ostra, que segue a orientação religiosa de algumas igrejas neopentecostais. Em relação à nova fé adotada pelo traficante Ostra, Mônica diz:

Hoje o cara que rege se converteu também, né? É de igreja evangélica. Aqui de vez em quando tem cultos, e tal, mas não se mete na religião de ninguém. Ele fala o seguinte: "cada um com a sua religião". Ele respeita. Ele já foi espírita, falou que teve desilusões na religião, e não quis mais; se afastou e virou evangélico. Mas ele não se mete, ele até ajuda.

Mônica se lembra de ter visto, muitas vezes, um famoso pastor, conhecido por evangelizar traficantes em presídios do Rio, realizar muitos cultos na Serrinha e ganhar bastante dinheiro com isso. Ela conta que ele foi expulso da favela quando um grupo de mulheres, incluindo a própria Mônica, descobriu que ele pagava pessoas para desmaiar nos cultos mediante um toque em seu no corpo: "Aí o pastor fazia aquele culto, aquela oração, aí fazia aquela roda de bandido... Os bandidos botavam os fuzis no chão, as mãos pro alto, orando ao senhor. E depois... E depois, davam tiro e continuavam vendendo a droga". Esse mesmo pastor também esteve inúmeras vezes nos cultos do baile funk do Dendê, na Ilha do Governador.

Mônica destaca uma grande resistência na constituição da favela da Serrinha, na afirmação de um espaço marcado, culturalmente, pelo jongo e pelo samba. A herança significativa dessa cultura afro-brasileira, preservada pelos esforços de rezadeiras, benzedeiras e jongueiros, está presente em todos os cantos da favela:

Aqui, a Serrinha é conhecida já como uma comunidade de grande resistência cultural. Os grandes fundadores da comunidade vieram de resistência, do cais do porto, do samba, do jongo, da escravidão. A gente já 
tá acostumado com resistência, então aqui é difícil conseguir acabar com alguma coisa, entendeu? Por isso que o jongo tá aí, vivo, por isso que o samba tá vivo, e outras culturas, a ladainha, a umbanda, e mais recente, o candomblé $[\ldots]$

Depois de ouvir os relatos de Mônica, decidi incluir a Serrinha em minhas pesquisas etnográficas e passei a frequentar a favela, observando seu cotidiano e conversando com os moradores. Tanto na Ilha, quando na Serrinha, tive minhas "incursões etnográficas" favorecidas pelo contato com adeptos das religiões afro-brasileiras e demais moradores da área. Apesar de pretender conversar com pastores e membros do varejo de drogas, essa foi a maneira mais segura que encontrei de começar o trabalho, tendo em vista que sou uma pesquisadora candomblecista. Neste trabalho constam as entrevistas que realizei, os rumores que ouvi, as cenas que presenciei e também àquelas que me foram contadas por terceiros.

Na Serrinha, minha entrada em campo foi facilitada pelos contatos que fiz na Casa do Jongo e, se nem todos os jongueiros ou frequentadores da casa são ligados à umbanda ou ao candomblé, também são raros os "evangélicos" que frequentam o espaço. Na Ilha, o fato de ser moradora do bairro, conhecer e testemunhar muitas histórias importantes para a tese me trouxe vantagens e desvantagens. Os riscos são maiores, pois sou uma candomblecista, filha de santo de um terreiro na localidade, estudando o processo de aproximação e também de violência entre o tráfico local e as religiões afro. No entanto tenho acesso a muitos contatos, justamente por ter nascido e vivido desde então no bairro.

A seguir, apresento algumas informações e relatos coletados na etapa inicial da pesquisa a partir de entrevistas e de conversas informais realizadas em campo, que no meu entendimento são representativos da complexidade das relações e dos códigos de conduta partilhados entre o tráfico e as religiosidades locais, com foco nos contrastes entre três favelas: Dendê, Barão e Serrinha.

\section{"A culpa é do Diabo": as religiões afro-brasileiras como focos do mal em favelas controladas por traficantes evangelizados}

É praticamente unânime entre os meios de comunicação, a polícia e os moradores da favela a informação de que o traficante Luiz e seus principais aliados residem no morro do Dendê, o principal ponto de venda de drogas na Ilha do Governador. Considerado a terceira maior favela carioca, o Dendê é dividido em diversas localidades, tais como: Boa Vista, Igrejinha, Tribo, Lixeirinha, Campinho, Riacho, Pracinha, Baviera e Zezinho. ${ }^{18}$ As notícias

\footnotetext{
18 Disponível em: MORRO DO DENDÊ. In: WIKIPÉDIA, a enciclopédia livre. Flórida: Wikimedia Foundation, 2020. Disponível em: <https://pt.wikipedia.org/w/index.php?title=Morro_do_Dend\%C3\%AA\&oldid=59197823>. Acesso em: 28 out. 2020.
} 
em torno de Luiz, ligadas à sua "invencibilidade" e à "conversão" ao evangelismo, tornaram sua fama tão grande que, em 2009, ele foi procurado e entrevistado pela revista norteamericana New Yorker, em matéria realizada pelo jornalista Jon Lee Anderson. Essa é, provavelmente, a única entrevista realizada face a face com o traficante que posou até para uma foto, divulgada na revista, na qual, aparece sentado no sofá da sua sala mostrando a tatuagem com o nome de Jesus Cristo no antebraço direito e cercado por quadros de salmos e mensagens bíblicas. ${ }^{19}$

A reportagem descreve o momento em que o traficante encontra sua nova fé através da intervenção do pastor Carlos dos Reis, da igreja Assembleia de Deus Ministério Monte Sinai, sediada na favela Parque Royal, conhecido na época por divulgar a palavra de Jesus entre os traficantes, vistos por ele como seres possuídos pelo demônio. Segundo o pastor, Luiz foi procurá-lo em busca de orações e conforto espiritual diante de um momento complicado, em que o Dendê havia se tornado um palco de guerra devido a uma série de confrontos com membros de uma facção rival. A igreja mencionada tem diversos ex-traficantes como membros e diáconos. Durante o culto, os fiéis dançam e entram em transes, identificados pelo pastor como "possessões demoníacas" logo "exorcizadas". ${ }^{20}$

Segundo os relatos do jornalista Jon Lee Anderson, durante a entrevista realizada com Luiz, ele orou bastante, chegou a ficar de joelhos na beirada da cama e mostrou conhecimento da palavra bíblica. Anderson, intrigado com a contradição vivida entre a fé religiosa e a vida no tráfico, perguntou aonde estava a divisão entre o certo e o errado para ele, que sorriu e respondeu: "Quem está decidindo?". ${ }^{21}$ Nas favelas da Ilha do Governador quem decide o limite entre o certo e o errado é o próprio traficante ${ }^{22}$ representante de um código de valores singular, resultado do seu domínio sobre os pontos de vendas de drogas e os "pedágios" cobrados por serviços diversos, do seu passado como adepto das religiões afro e do seu presente evangelizado.

Guiado pela nova fé religiosa, o traficante instalou autofalantes nos becos para que todo o Dendê ouvisse cultos e orações diariamente, e mandou escrever a frase "Isso pertence a Jesus Cristo" no muro atrás da enorme piscina construída na favela para o lazer dos moradores. Segundo alguns relatos, inclusive do pastor Carlos, ele teria parado de praticar

\footnotetext{
${ }^{19}$ ANDERSON, J. L. Gangland: Who controls the streets of Rio de Janeiro? The New Yorker, New York, p. 46-57, 5 out. 2009. Disponível em: <http://www.newyorker.com/magazine/2009/10/05/gangland>. Acesso em:

${ }^{20}$ ANDERSON, loc. cit.

${ }^{21}$ Ibid., p. 57.

${ }^{22}$ Sob o ponto de vista religioso, ele se coloca no lugar do próprio Deus ao definir o que é certo e o que é errado nas favelas sob seu domínio.
} 
assassinatos durante algum tempo, logo após a "conversão" e também, a partir daí, teria proibido os assaltos na Ilha. Além disso, como já foi mencionado, mandou fechar todos os terreiros de umbanda e candomblé do Dendê e de outras favelas. Vários dos seus aliados traficantes também passaram a propagar a nova fé, ligada, principalmente, às igrejas neopentecostais. Moradora do Dendê há mais de 30 anos, Flora me contou:

Os traficantes não aceitavam qualquer outra religião, principalmente a espírita. Não tinha tolerância nenhuma à espírita. Ou seja, você não tinha direito a usar o seu branco, você não tinha direito a usar seus fios de conta [...]. Você não tinha não, você não tem o direito de usar seus fios de conta, de usar seu branco, de lavar sua roupa, de estender na sua casa ao ar livre pra secar.

A tensão entre o tráfico e os terreiros foi se desenrolando sem que o chefe do tráfico expressasse claramente o motivo pelo qual proibiu o funcionamento de casas de umbanda e candomblé na área. Também não houve unanimidade nas ações atribuídas aos traficantes para impedir esses lugares de funcionar. Em alguns casos, os pais de santo receberam avisos para se retirarem da favela e fecharem os terreiros, em outros, foram interrompidos de forma violenta durante as cerimônias religiosas, torturados e humilhados publicamente.

A mãe de santo Nara, por exemplo, conta uma história singular, pois um grupo de traficantes armados chegou à sua casa e a levou junto com todos os seus "assentamentos de santo" (locais sagrados onde são cultuados os orixás) para uma praia na Ilha do Governador, onde eles foram lançados ao mar, garantindo assim que fossem devidamente "despachados" (jogados fora). Nara ficou muito surpresa com a atitude, pois identificou naqueles homens um conhecimento profundo dos códigos religiosos do candomblé, uma vez que o ato consiste em eliminar permanentemente o orixá cultuado, sem a possibilidade de que o assentamento seja refeito. A ex-mãe de santo nunca mais abriu um terreiro. Outros sacerdotes recomeçaram sua trajetória espiritual com novas "casas de santo", em locais fora das favelas, no próprio bairro da Ilha do Governador, ou em regiões mais distantes, como a Baixada Fluminense.

Os terreiros começaram a sofrer proibições mais sistemáticas a partir de 2008, mas as sanções sofridas pelos religiosos da umbanda e do candomblé não ocorreram de maneira repentina, e sim ao longo de um processo que se estendeu por anos. Ao longo desse tempo, meus interlocutores elegeram alguns "gatilhos", ou seja, fatos considerados primordiais para o desdobramento dos momentos mais críticos vividos após a "conversão" do chefe do tráfico. De maneira cronológica, pude sistematizar alguns deles. O primeiro diz respeito à nova religião do traficante. Existem muitos rumores sobre a adoção dessa nova fé por Luiz. Algumas pessoas acreditam que não existe uma fé genuína e verdadeira em suas intenções, 
que seriam puramente mercadológicas e estratégicas, assim como a maior parte das suas ações. Outras pessoas acreditam que a nova religião se tornou seu grande alicerce para suportar a tensão e a instabilidade da posição de comando no varejo de drogas, que está sujeita a disputas frequentes com facções rivais e, muitas vezes, com os próprios aliados. Como sua mãe frequenta uma igreja evangélica neopentecostal há anos, o convencimento da família consiste em outro rumor frequente. Sua suposta decepção com o candomblé também gera muitas histórias: alguns moradores dizem que ele teria passado por uma cerimônia de fechamento do corpo ${ }^{23}$ no passado, mas sua eficácia foi posta em dúvida durante uma invasão de uma facção rival na favela.

Outro momento crítico importante foi quando ele mandou fechar os terreiros de umbanda e candomblé. Um dos boatos mais propagados conta que a principal motivação surgiu quando ele encontrou seu nome escrito em um papel dentro de uma "macumba" ${ }^{24}$ na favela. A partir daí diversos pastores teriam começado uma ostensiva campanha de difamação das religiões afro-brasileiras na área, identificando os eventos negativos que aconteciam, como mortes, invasões e trocas de tiros, à presença dos terreiros. Em 2019, passados doze anos do início dos conflitos religiosos no bairro, existe, segundo os moradores, uma flexibilização maior em relação à permanência e à manutenção das religiões afrobrasileiras, o que também gera muito burburinho sobre uma suposta reaproximação do traficante com o candomblé. Outros moradores dizem que a amenização dos conflitos se deve à atuação conciliadora do atual pastor que aconselha o traficante, uma vez que ele seria menos combativo em relação a outras religiões.

O local conhecido como morro do Barão, também na Ilha do Governador, corresponde à junção de três favelas: Duas Praias, Prefeitura e Caixa d'água, com tamanho bem inferior ao território que hoje corresponde ao Dendê. No local, existe atualmente quatro terreiros e duas igrejas, uma de denominação neopentecostal e outra Batista. Entrevistei dois sacerdotes locais, Ronaldo e Vera, e seus respectivos filhos de santo, e também alguns moradores.

Ronaldo é o atual pai de santo de uma casa de candomblé localizada no Barão desde 1950. Iniciado há 27 anos no candomblé, ele me contou que seu barracão de santo ${ }^{25}$ nunca foi impedido de realizar cerimônias e, no passado, costumava ser frequentado por alguns

\footnotetext{
${ }^{23}$ O fechamento de corpo é uma cerimônia muito popular nas religiões afro-brasileiras. De maneira bastante resumida trata-se de proteger um corpo material de ameaças espirituais, como energias negativas que gerem doenças e desequilíbrios emocionais. No entanto suas interpretações são múltiplas, e algumas pessoas acreditam que sua potência é tão grande que seria capaz de impedir que o corpo sofra qualquer tipo de imprevisto ruim, como, por exemplo, um acidente, um tiro ou a morte.

${ }^{24}$ Nome como as pessoas chamam as oferendas colocadas na rua por adeptos da umbanda e do candomblé. As próprias religiões afro-brasileiras são, genericamente, e por vezes pejorativamente, identificadas como "macumba".

${ }^{25}$ Expressão equivalente a terreiro, templo dos santos (orixás).
} 
traficantes. Sobre isso, ele é taxativo: "minha casa não discrimina ninguém, mas nunca foi conivente com o tráfico, diferentemente desses pastores por aí que até benzem as armas dos bandidos antes de ir pra guerra". De acordo com o pai de santo, algumas igrejas neopentecostais incentivam e encobrem crimes dos traficantes em troca dos dízimos e de divulgação na favela. E ele garante que até hoje, mesmo após a "conversão" de Luiz, é procurado por alguns "bandidos", que pedem seu auxílio, mas de maneira silenciosa, por medo de represálias.

Por volta de 2008, Ronaldo presenciou o fechamento das "casas de santo" do Dendê e a violência com que foram tratados muitos pais de santo, em grande parte seus amigos. Na época, as pessoas estavam com muito medo de fazerem seus "toques" e, pressionado por alguns amigos, ele acabou indo até o Dendê para falar pessoalmente com Luiz e garantir que fosse mantido seu calendário de festas. Recebido por um "gerente" do grupo do traficante foi-lhe dito que não havia proibição quanto ao funcionamento de terreiros no Barão. Ronaldo lembra que muitos filhos de santo, moradores do Dendê, viveram tempos de medo e chegaram a levar suas roupas de santo para lavar em sua casa, com medo de serem descobertos:

Foi março de 2008. Eu tinha que botar amalá ${ }^{26}$ pra Xangô. Ia fazer como fazia sempre mesmo, né? Eu não ia parar. Aí toquei o atabaque, todo mundo ficou com medo, aquela coisa mesmo... E logo depois dessa amalá, eu queria dar a festa de Ogum. E eu queria dar a festa de Ogum porque eu tinha saído do hospital, pra agradecer não só a Ogum, mas a todos os orixás, porque eu estava ali seis meses no hospital, né? Aí todo mundo ficou falando "ah, não faz, não faz, não faz". Foi quando eu resolvi ir ao traficante e perguntar se eu podia fazer a festa, né? E foi quando ele falou, não olhou pra mim, estava de costas, eu não conheço ele, estava de costas bem longe, e falou que eu podia fazer e que lá não tinha problema nenhum.

Em frente ao barracão de Ronaldo existe uma igreja Batista. Ele conta que já houve conflitos com os pastores, mas que foram superados pelas situações de paz. No mesmo ano em que foi no Dendê pedir autorização para realizar seu candomblé, ele, que havia passado por internações e complicações de saúde, recebeu a visita dos irmãos evangélicos, obstinados a fazer orações pela sua saúde. Ronaldo disse para eles que poderiam fazer as orações desde que acontecessem em frente ao quarto de Xangô, seu orixá "de cabeça” (expressão usada para dizer que a pessoa foi iniciada no candomblé a partir daquele orixá) e guardião da sua casa. $\mathrm{E}$ assim foi feito:

\footnotetext{
${ }^{26}$ Amalá é a comida ritual oferecida ao orixá Xangô. No candomblé é feito com quiabo cortado, cebola, camarão, sal, azeite de dendê e carne vermelha.
} 
É, quando eu fiquei doente, porque alguns membros da igreja conheciam minha família. Inclusive o pastor. E quando eu retornei, nesse mesmo período de 2008, eles foram fazer uma oração pra mim. E eles perguntaram aonde é que podia orar. Eu falei é da porta do quarto de Xangô, que é onde lá dorme o meu Deus, que é Xangô. Vocês têm Jeová e eu tenho Xangô. E eles fizeram oração na porta do quarto de Xangô. Ali era meu templo. E eu fiquei de olho fechado, orei também, porque toda reza é bem-vinda, né?

Ronaldo me contou que uma vez tentaram colocar uma "boca de fumo" no Barão, no entanto "ela só durou meia hora, a polícia veio logo e acabou com tudo". Segundo ele, a região do Barão era toda composta por terrenos do Instituto Nacional de Previdência Social (INPS) para abrigar seus funcionários na década de 1960, que foram invadidos posteriormente. $\mathrm{O}$ morro é dividido entre barracos de madeira ou casas de tijolo simples até mansões, ocupadas, segundo Ronaldo, por policiais civis, militares e até um delegado, por isso a dificuldade de estabelecer pontos de venda de drogas na área.

João é mestre de capoeira e faz parte de um projeto social no Dendê que ensina o esporte para crianças carentes. Por receber apoio financeiro da associação de moradores, ele foi orientado a esconder sua religião desde a "evangelização" do traficante, e passou a encontrar seu pai de santo, o pai Ronaldo, do morro do Barão, já mencionado, às escondidas, para não sofrer ameaças do tráfico. Também precisou alterar o nome do seu grupo de capoeira, que incorporou uma referência bíblica. Segundo João, a capoeira foi demonizada pelas "igrejas evangélicas atuais" por estar ligada à tradição africana e, consequentemente, ao candomblé, no entendimento desses grupos. Entretanto a atividade é bastante popular no Dendê, e não foi proibida por Luiz, desde que passasse a incorporar alguns símbolos cristãos.

Além de João, outros moradores do Dendê frequentam o terreiro de pai Ronaldo às escondidas:

Tem pessoas que frequentam a minha casa que são de lá, que inclusive vêm escondidos, que moram no Dendê, que vêm escondido. [...] Vem escondido, não pode lavar roupa, bota na corda as roupas brancas, as pessoas todas. Suzana era uma, agora Suzana tá lavando roupa. Antigamente, a roupa da Suzana ficava aqui em casa. A Lia é uma pessoa que se esconde, não anda de branco lá.

Pai Ronaldo lamenta toda onda de demonização das religiões afro-brasileiras:

E é muito difícil pro candomblé, ou pra umbanda, pro espiritismo, seja lá o que for, porque... O que que acontece... O pastor, as igrejas evangélicas, elas ficam 24 horas fazendo uma lavagem cerebral nas pessoas. Se o cara foi 
desempregado, foi a macumba; se o marido brigou com a mulher, foi a macumba, se não tem comida, foi a macumba, foi o diabo né? Eu não conheço o diabo, porque o diabo é coisa da Igreja Católica. Eu sou candomblecista. Eu conheço deuses. Então enquanto tiver essas pessoas fazendo lavagem cerebral nos outros, e são pessoas fracas, isso vai continuar. Mesmo que o traficante não fique aí, mas vai ter outras pessoas que isso vai continuar. [...] Demonizando, demonizando. Eles demonizam tudo.

A mãe de santo Vera tem uma casa de umbanda no Barão há mais de 20 anos e nunca sofreu ameaças dos traficantes. Perto da sua residência há uma igreja neopentecostal que já lhe causou alguns aborrecimentos, pois uma das irmãs evangélicas começou a implicar com sua casa, demonizando suas cerimônias religiosas e proferindo palavras de ódio. Vera afirma que nunca se sentiu ameaçada ou intimidada por bandidos e nem evangélicos, pois tem certeza de que a sua religião não evoca o Diabo, apenas o amor e a caridade. Durante o tempo em que estive em sua casa, foi possível observar filhos de santo circulando pela área com suas vestimentas brancas e fios de conta, sem o menor receio.

Logo no início do estudo de campo na Serrinha, ouvi muitas pessoas defenderem que a favela é um dos poucos lugares no Rio de Janeiro onde o varejo de drogas ainda respeita o morador e que, apesar de o chefe do tráfico, Ostra, estar sob orientação religiosa neopentecostal, não havia violência e nem sansões aos moradores e às casas religiosas que professassem outra religião. Todavia, com o passar dos meses, observando o comportamento dos moradores durante as conversas, pude verificar um total desconforto em falar sobre o assunto. A maioria das pessoas diz que a Serrinha abarca uma grande pluralidade religiosa e que não há problemas do tráfico com isso, porém insinuam uma forte ligação entre algumas igrejas e as atividades ilícitas propagadas pelos traficantes, como a venda de drogas e armas.

Depois de muitas tentativas frustradas consegui conversar com Vó Nitinha, uma das moradoras mais antigas da Serrinha, herdeira de um importante terreiro. Pela idade avançada, Vó Nitinha não está mais à frente do terreiro, mas ainda mantém a prática de rezar as crianças e os doentes, e acompanha algumas festas sagradas, como o dia de São Jerônimo, identificado como Xangô na umbanda, todos os anos, no dia 30 de setembro. Contaram-me que uma vez tentaram acabar com a festa:

Houve uma época que a Igreja Universal vinha evangelizar aqui, subia a Balaiada... Lá no alto da Balaiada tem a pedreira de Xangô. Eles iam lá e quebravam o santo, quebrava as oferendas, as comidas do santo, né? Aí a comunidade começou a fazer queixa, que na época era o Mequinho também, nessa época aí, e o Mequinho proibiu eles de subir: "Não vão subir. Vocês podem evangelizar na rua, lá na Pedreira de Xangô, não". 
Subindo uma das ruas que dá acesso à casa da Vó Nitinha pude identificar que todos os muros das casas estavam pintados com mensagens bíblicas, menos o dela. Essa foi uma das primeiras impressões que compartilhei em nossas conversas, ela respondia rindo: "aqui no muro não, falei logo, não quero esses bandidos, tudo ex-alguma coisa agora metido a evangélico vindo pichar meu muro". Ela explicou que os grafites foram feitos por iniciativa de um centro "evangélico" de reabilitação para usuários de drogas, que ocupa os pacientes em recuperação, entre eles ex-traficantes, com esse trabalho.

Ficamos no quintal conversando, com a porta da sua casa aberta, como sempre deixa, e ela falava com naturalidade sobre os traficantes locais: "a maioria desses meninos eu vi nascer, fiz o parto. Tá vendo essas garotos aí, eu que botei no mundo, minha filha". Disse que os traficantes a respeitam e que acha contraditório um "bandido ser evangélico". No entanto, no momento que pedi para tirar uma foto ao seu lado na porta de casa, ela hesitou, disse que eu podia tirar, mas muito rápido para os meninos do tráfico não virem e acharem que eu estava investigando alguma coisa sobre eles. Algumas vezes, enquanto conversávamos, fomos interrompidas pela passagem de algumas motos com homens armados. Vó Nitinha preferia conversar sem sentir que estava sendo observada ou ouvida por eles.

Consegui conversar com outra mulher importante na Serrinha, também jongueira e umbandista. Neusa me mostrou a casa onde mora e onde funciona um antigo terreiro. No quintal, há um altar de vidro para Xangô e São Jerônimo, que é possível ver da rua. Realidade bem diferente dos adeptos das religiões afro-brasileiras que vivem no Dendê, na Ilha, que não conseguem sequer estender suas roupas brancas no varal. Ela me contou que o tráfico respeita bastante a longa tradição cultural e religiosa da Serrinha, propagada por mulheres negras jongueiras e mães de santo. Segundo ela "os bandidos morrem de medo de Vó Nitinha e das suas mandingas". Ela lamenta o aumento da violência com constantes tiroteios entre facções rivais na área, mas demonstra grande afetividade para com a favela que nasceu e pretende morar até morrer. Também me disse que antes dos bailes funks são feitos cultos e orações, o que para ela é uma grande contradição, entre o momento religioso e a festa profana com músicas eróticas e que fazem apologias ao tráfico. $\mathrm{O}$ muro da sua casa estava pintado com salmos; perguntei o que achava a respeito, e ela me disse: "quando eu cheguei já estava assim, ninguém me perguntou", com uma expressão de aborrecimento, mas não quis comentar mais nada.

Conheci Laura na Casa do Jongo, no mesmo dia que conheci Mônica. Laura é jongueira e capoeirista, mora na Ilha do Governador e me disse que sabia muitas coisas sobre o traficante Luiz e sua aproximação com a igreja "evangélica". Laura me contou que usava muitas drogas na época que ele se "converteu" no Dendê, e por isso conviva bastante com os "meninos do tráfico". Ela trabalhou em um projeto comunitário, comandado por um pastor, como 
professora de informática, em 2006, na favela do Guarabu, que é vizinha à favela ao Dendê. Esse pastor era o responsável por arrecadar o dinheiro destinado ao projeto, que vinha em nome da associação de moradores, mas na verdade era fornecido pelo tráfico. A partir dessa experiência que ela começou a perceber uma ligação crescente entre a "Igreja" ${ }^{27}$ e o tráfico nas favelas da Ilha: "Você não pode colocar um despacho na rua, que corre o risco de levar pedrada. Lá é muito complicado. É muita casa invadida, é muita casa invadida mesmo. Teve uma que foi invadida três vezes e ele acabou fechando".

Laura me contou que no Dendê os traficantes evangelizados justificam os assassinatos cometidos com uma passagem bíblica: "porque o salário do pecado é a morte, mas o dom gratuito de Deus é a vida eterna em Cristo Jesus, nosso Senhor". ${ }^{28}$ Segundo ela: "O salário do pecado é a morte, a traição é o pecado. Então como a traição é um pecado, não é um pecado você estar matando uma pessoa, porque o salário é a morte né? O salário do pecado é a morte". Ou seja, a chamada "morte justa", que é a sentença para o traidor, para alguém que "vacilou" no morro ou para os inimigos, não é pecado: "Essa é a justificativa pra poder matar, sem ter a culpa do sangue na mão".

Laura contou ainda que presenciou a época em que alguns pastores começaram a fazer uma propaganda negativa e demonizante das religiões afro-brasileiras no Dendê e por tudo que acontecia de errado na favela acusavam as casas de umbanda e candomblé que existiam lá: "Os pastores, eles começaram a demonizar as religiões africanas que haviam em cima do morro, na época que comecei a frequentar o morro, eu comecei a ver isso, e aí tudo que começou a dar errado lá em cima, eles começaram a dizer que era porque havia esses centros". Ela acredita que, por influência desses religiosos, Luiz mandou fechar todos os terreiros da favela: "Se acontecia uma invasão, se morria alguém, eles falavam que era porque tinham pessoas que eram ligadas a isso, que tavam fazendo macumba pra acabar com fulano, sicrano e beltrano...". Outras pessoas, tal como Laura, já haviam me contado que a aproximação do traficante com as igrejas neopentecostais teria ocorrido em um momento crítico da sua vida, quando houve disputas internas crescentes pelo controle do tráfico.

Para Laura, existe uma ligação financeira entre o tráfico e algumas igrejas neopentecostais, mas também existe outro fator que colabora com a evangelização dos criminosos: o apoio emocional e psicológico dado pelos pastores somado à promessa de salvação:

\footnotetext{
${ }^{27}$ Laura chama genericamente de igreja os templos de denominação pentecostal e neopentecostal.

${ }^{28}$ Romanos 6:23, versão da Bíblia Almeida Revista e Atualizada. Disponível em: <https://www.bible.com/pt/bible/1608/ROM.6.ARA>. Acesso em: 28 out. 2020.
} 
Bandido é carente, não tem essa assim. Não sei se você tem ideia, se já conviveu com algum, mas bandido é muito carente, porque são pessoas muito mal resolvidas na vida, com problemas psicológicos imensos [...]. O pessoal da igreja começou a fazer isso, a dar aquele apoio, o paizão, o pessoal que vai orar, "vamos ajudar", "vamos salvar fulano", "vamos salvar sicrano" e tal, e nesse meio tempo, o que que eles fizeram? Eles construíram estrategicamente um exército pra limpar os candomblés e as casas de umbanda do morro [...]. Ah, eu acho que o interesse mais é a questão, assim, afetiva mesmo, espiritual. Porque eles [os bandidos] se sentem resguardados espiritualmente, porque muitos deles têm esse medo né, de morrer, ir pro inferno...

Assim, a persona do traficante reúne em torno de si muitas facetas: a do bandido em busca de salvação, mas também de perdão e de reconhecimento; é o homem poderoso e rico o suficiente para assistir os mais pobres e, ao mesmo tempo, poderoso e juiz do destino, de vida ou de morte das pessoas, cruel e implacável diante dos inimigos.

Em outro momento, Laura mencionou mais uma questão relacionada ao fechamento de "casas de santo" ${ }^{29}$ por traficantes: a falta de credibilidade. Em uma escala moral que qualifica os sacerdotes das religiões afro, a credibilidade foi mencionada em vários depoimentos de moradores das favelas da Ilha do Governador e da Serrinha. Mauro, pai de santo de umbanda que tem um terreiro em um bairro próximo ao morro do Dendê, me disse que a credibilidade foi um dos fatores decisivos para que Luiz expulsasse mães e pais de santo escolhidos da favela. Segundo ele, muitos dos líderes espirituais que foram expulsos tinham condutas duvidosas na localidade, extorquiam clientes e faziam trabalhos espirituais para prejudicar as pessoas. Ele conheceu pessoalmente alguns deles e acredita que apesar da iniciativa do traficante ser lamentável, ela contribuiu para separar "o joio do trigo". Pois, segundo Mauro, as casas de santo que ainda sobrevivem na Ilha do Governador têm procurado fazer um trabalho honesto e confiável, evitando motivo para represálias.

Laura também menciona que a falta de credibilidade de algumas casas foi fator preponderante desse processo. Na Serrinha, palavras como "respeito", "credibilidade" e "tradição", são acessadas, comumente, para identificar as casas religiosas que permanecem por décadas na favela e não são ameaçadas pelo tráfico.

\footnotetext{
${ }^{29}$ Casas religiosas de umbanda e candomblé. 


\section{Considerações finais}

Pensar na "credibilidade" dos sacerdotes e em todos os repertórios morais que são acessados para compreender a evangelização de um traficante e a demonização dos templos religiosos umbandistas e candomblecistas nas favelas supracitadas, complexifica a questão da violência religiosa, que não está ligada apenas ao traficante "convertido", mas aos pais e às mães de santo que ele ameaça, a trajetória construída por eles na favela e a relação de ambos com os moradores. Tanto Laura quanto Mauro são umbandistas e utilizam a credibilidade como critério para avaliar a própria religião. Entretanto essa não é uma relação simétrica: quem tem o poder de fogo são os traficantes, que decidem quem vive e quem morre.

Os moradores das favelas da Ilha do Governador e da Serrinha, sejam eles adeptos das religiões afro-brasileiras, traficantes, pessoas comuns ou pastores e membros das igrejas (neo)pentecostais, buscam até hoje elaborar uma interpretação, com base em suas experiências pessoais e coletivas, que justifique a proibição e/ou as sanções a terreiros nessas localidades. Assim, os rumores, além de trazerem informações e possíveis explicações para os casos, ajudam a compreender a maneira como impactam a rotina dos moradores dentro dessas favelas. O foco dessa pesquisa etnográfica não está nos eventos, nas notícias e nas ações "oficiais", legitimadas por algum tipo de poder legal ou ilegal, mas nos próprios moradores, no caso, primordialmente, dos adeptos das religiões afro-brasileiras, que buscam meios de comunicação, sobrevivência e (re)existências nessas áreas.

A lógica do vareo de drogas, das religiões afro-brasileiras e da nova fé adotada pelos traficantes, representada pelas igrejas (neo)pentecostais, está interligada ao cotidiano dos moradores e é primordial para o trabalho que estou desenvolvendo. Serão caros à pesquisa as memórias, os rumores, as vivências e as convivências observados e/ou relatados no cotidiano das populações desses espaços.

\section{Referências}

ALMEIDA, R. A expansão pentecostal: circulação e flexibilidade. In: TEIXEIRA, F.; MENEZES, R. (Orgs.). As religiões no Brasil: continuidades e rupturas. Petrópolis: Vozes, 2006.

BIRMAN, P.; LEITE, M. P. O que aconteceu com o antigo maior país católico do mundo? In:

BETHELL, L. (Org.). Brasil: fardo do passado, promessa do futuro. Dez ensaios sobre política e sociedade brasileira. Rio de Janeiro: Civilização Brasileira, 2002.

BRUM, M. S. Favelado: a construção de uma identidade na história do Rio de Janeiro. In: ENCONTRO REGIONAL DE HISTÓRIA: DEMOCRACIA E CONFLITO, II., 2004, Rio de Janeiro. Anais... Rio de Janeiro: Anpuh, 2004. vol. I. 
CARDOSO, C. Análise das diferentes representações e concepções das favelas do Rio de Janeiro influenciando na construção da identidade local. In: ENCONTRO DE GEÓGRAFOS DA AMÉRICA LATINA, I2., 2009, Montevidéu. Anais... Montevideo: 2009. vol. I.

CUNHA, C. V. da. Conflitos religiosos e a construção do respeito à diversidade: breve histórico e iniciativas recentes. Comunicação e Transformação Social 2. , São Leopoldo: Editora Unisinos, 2012. p. 95-I22.

CUNHA, C. V. da. Da macumba às campanhas de cura e libertação: a fé dos traficantes de drogas no Rio de Janeiro. Tomo, Universidade Federal de Sergipe, v. I4, p. 229-265, 2010.

CUNHA, C. V. da. Evangélicos em ação nas favelas cariocas: um estudo sócio-antropológico sobre redes de proteção, tráfico de drogas e religião no complexo de Acari. 2009. Tese (Doutorado) - Programa de Pós-Graduação em Ciências Sociais, Universidade do Estado do Rio de Janeiro, Rio de Janeiro, 2009.

CUNHA, C. V. da. Oração de traficante: uma etnografia. Rio de Janeiro: Garamond, 2015.

GRYNSZPAN, M.; PANDOLFI, D. A favela fala: depoimentos ao CPDOC. Rio de Janeiro: FGV, 2003.

MAFRA, C. Censo de religião: um instrumento descartável ou reciclável? Religião e Sociedade, v. 24, n. 2, 2004.

MAGGIE, Y. Medo do feitiço: relações entre magia e poder no Brasil. Rio de Janeiro: Arquivo Nacional, 1992.

MARIANO, R. Neopentecostais: sociologia do novo pentecostalismo no Brasil. São Paulo: Edições Loyola, 1999.

MENEZES, P. Os rumores da "pacificação": a chegada da UPP e as mudanças nos problemas públicos no Santa Marta e na Cidade de Deus. Dilemas, Revista de Estudos de Conflito e Controle Social, v. 7, p. 665-683, 2014.

PEREIRA, V.P. Mentalidade iconoclasta e direito à liberdade religiosa na sociedade plural: o caso da destruição de centros espíritas no Rio de Janeiro. Revista de Direito da Cidade, Rio de Janeiro, v. 5, n. I, 2013.

PIERUCCI, A. F. de O. Secularização e declínio do catolicismo. In: SOUZA, B. M. de; MARTINO, L. M. S. (Orgs.). Sociologia da religião e mudança social: católicos, protestantes e novos movimentos religiosos no Brasil. São Paulo: Paulus, 2004. p. I3-21.

REINHARDT, B. Espelho ante espelho: a troca e a guerra entre o neopentecostalismo e os cultos afro-brasileiros em Salvador. São Paulo: Attar Editorial, 2007.

SILVA, V. G. da (Org.). Intolerância religiosa: impactos do neopentecostalismo no campo religioso afro-brasileiro. São Paulo: Edusp, 2007. 
TEIXEIRA, C. P. O pentecostalismo em contextos de violência: reflexões sobre religiosidade popular. 2006. Monografia em Ciências Sociais - Instituto de Filosofia e Ciências Humanas, Universidade do Estado do Rio de Janeiro, Rio de Janeiro, 2006.

TELLES, V. S.; HIRATA, D. Cidade e práticas urbanas: nas fronteiras incertas entre o ilegal, o informal e o ilícito. Revista de Estudos Avançados da USP, v. 2I, n. 6I, p. I7I-I9I, 2007.

VALLADARES, L. do P. A invenção da favela: do mito de origem à favela.com. Rio de Janeiro: FGV, 2005.

ZALUAR, A.; ALVITO, M.(Org.). Um século de favela. Rio de Janeiro: FGV, 1998. 